\title{
Müzik Tarihine ve Kültürel Müzikolojiye Sunduğu Katkılar Açısından Bahaeddin Ögel
}

\section{Feyzan GÖHER*}

\begin{abstract}
ÖZ
Genel Türk Tarihi alanının en önemli biliminsanlarından olan Prof. Dr. Bahaeddin Ögel, kültürel tarih açısından son derece kıymetli eserlere imza atmıştır. Onun kapsamlı eserleri, tarihin yardımcı olduğu diğer alanlara da veri sunmaya devam etmektedir. Bahaeddin Ögel'in eserlerinin en fazla 1şık tuttuğu yan disiplinler, folklor ve müziktir. Genel Türk tarihi veya mitoloji konulu yapıtlarında çok sayıda müzikolojik veriye rastlamak mümkündür. Öyle ki onun eserlerine başvurulmadan yazılmış Türk müzik tarihi çalışmaları, yetersiz kabul edilir. Bunların yanı sıra Ögel'in müstakil olarak müzikoloji konulu kitapları ve tebliğleri vardır. $\mathrm{O}$, tarih biliminden getirdiği disiplinle, vesikalara dayalı metodolojik müzikoloji yazımına da katkılar sunmuştur. Müzik tarihi, organoloji (çalgı bilim), kültürel müzikoloji gibi pek çok alt branşa veri sunan eserleri, bu eserlerin içeriği, ne gibi yenilikler ve öneriler getirdiği, hangi kapıları açtı̆̆ı, Bahaeddin Ögel'in müzikle olan ilişkisinin temeli, bu makalenin odaklandığı hususlardır.

Betimsel karakterli bu çalışmada literatür taraması ile birlikte, Ögel'in öğrencisi olmuş kıymetli biliminsanlarının görüşlerine de başvurulmuş; yarı yapılandırılmış görüşme tekniğine dayalı olarak kendilerinden konu ile ilgili bilgiler edinilmiştir.

Çalışmada Prof. Dr. Bahaeddin Ögel'in müzikoloji alanında veriler içeren eserleri saptanmış; bu çalışmaların hangi alt dallara 1 ş1k tuttuğu incelenmiştir. Ögel'in müzikolojiye veri sunan eserlerini genel olarak ikiye ayırmak mümkündür. İlki, temelde Genel Türk Tarihi veya mitoloji konulu olan ama içerisinde çeşitli alt başliklar içinde müzikolojik veriler barındıran eserler; diğeri ise Türk Kültür Tarihine
\end{abstract}

Prof. Dr., Niğde Ömer Halisdemir Üniversitesi, Türk Musikisi Devlet Konservatuvarı, Müzikoloji Bölümü, Niğde/Türkiye

E-posta: feyzan_goher@yahoo.com, ORCID: 0000-0001-5313-0763,DOI: 10.32704/erdem.948843 Makale Gönderim Tarihi: 14.08.2020 * Makale Kabul Tarihi: 26.03.2021 * (Araştırma Mk.) 
Giriş serisinin sekizincisi olan "Mehter" ve dokuzuncusu olan "Türk Halk Musikisi Aletleri” gibi doğrudan müzikolojiyi ilgilendiren eserlerdir. Çalışmanın sonunda Ögel'in müzikolojik bilgiler barındıran kitapları, makaleleri ve tebliğleri listelenmiştir. En son olarak Ögel'in müzikoloji alanına sunduğu katkılar tablolaştırılmıştır. Bu katkılar ana başlıklar halinde şu şekilde tespit edilmiştir: Türk müzik tarihine ilişkin veriler (kronolojik gelişim ve değişimler), Türk müzik türlerine ilişkin bilgiler, Türklerde askeri müzik (tuğ, nevbet, mehter teşkilatları, görevleri, çalgıları), Organolojik bilgiler (çalgıların kökenleri konusunda bilgiler, çalgıların sınıflandırılması vb.), Müzik ve mitoloji konulu bilgiler (efsanelerde müzik, müzisyen ve çalgılar; çalgıların yaradılış efsaneleri vb.), Müzik ile ilişkili kelimelere yönelik bilgiler (üzerinde tartışma bulunan müzikal kelimeler hakkında tanımlama ve tartışmalar; Türk dünyasında karşıllı̆ğ olan ancak Anadolu Türklerince pek fazla bilinmeyen müzikal kelimelerin tanıtımı; aynı isimli bir çalgının farklı Türk topluluklarında aldığı isimsel ya da biçimsel farklılıkların tespiti vb.)

Anahtar Kelimeler: Bahaeddin Ögel, genel Türk tarihi, müzik tarihi, kültürel müzikoloji. 


\title{
Bahaddin Ögel's Contributions to Music History and Cultural Musicology
}

\begin{abstract}
One of the most important scientists in the field of General Turkish History, Prof. Dr. Bahaeddin Ögel had written very valuable works in terms of cultural history. His extensive works continue to shed light on other areas in which history has helped. One of these fields is the history of music, which is a sub-branch of both musicology and history. The side disciplines that Bahaeddin Ögel's works shed the most light on are folklore and music. It is possible to come across many musicological data in his works on general Turkish history or mythology. So much so that Turkish music history studies written without reference to his works are considered insufficient. In addition to these, Ögel has books and papers on musicology. With the discipline he brought from the science of history, he also contributed to methodological musicology writing based on documents. The main subject of this study is Ögel's works on music history, organology, cultural musicology, the content of these works, and Bahaeddin Ögel's relationship with music.
\end{abstract}

In this descriptive study, the opinions of valuable scientists who were his students have been consulted along with the literature review; based on the semi-structured interview technique, information on the subject was obtained from them.

In the study, Ögel's works containing data in the field of musicology have been determined; the sub-branches these studies shed light on have been examined such as music history, organology, cultural musicology. It is possible to divide Prof. Dr. Bahaeddin Ögelıs works that present data to these fields into two. The first is the works that are mainly about General Turkish History or mythology, but contain musicological data in various sub-titles. The other is individual works that directly concern musicology, such as "Mehter" and "Turkish Folk Music Instruments". At the end of the study, Ögel's works on musicology have been classified. His books, articles and papers written independently on music or other subjects but containing musicological information have been listed. Finally, Ögel's contributions to the field of musicology have been tabulated. These contributions have been identified under the main headings as follows: Data on Turkish music history (chronological development and changes), information on Turkish music types, military music in Turks (tuğ, nevbet, mehter teams, duties, instruments), Organological information (information on the origins of instruments etc.), Information on music and mythology 
(music, musicians and instruments in legends etc.), Information on words related to music (definitions and discussions on musical words on which there is a discussion; Introduction of musical words not well known to Anatolian Turks)

Keywords: Bahaeddin Ögel, general Turkish history, music history, cultural musicology. 


\section{Giriş}

$\mathbf{M}$ ehmet Altay Köymen, Bahaeddin Ögel’i “dünyadaki en büyük Orta Asya Türk tarih ve medeniyeti uzmanı" olarak tanımlamıştır (Köymen, 1989:61). Ögel, bu haklı tanımlamayı birbirinden değerli yapıtları ile hak etmiştir. O, Türk tarihinde kimsenin kolay kolay çalışmaya cesaret edemediği alanları, büyük bir özveri ile araştırmış; internetin etkisiz olduğu, Orta Asya Türk dünyasına ulaşımın rahat olmadığı bir dönemde yaşamış olmasına karşın, Çin'den Almanya'ya kadar pek çok ülkede, bilimin ve Türk kültürünün peşinden koşmuş; sadece tarih alanı için değil, çok sayıda sosyal bilim için de eşsiz eserler ortaya koymuştur.

Bahaeddin Ögel'in Türk tarihi veya mitoloji konulu yapıtlarında çok sayıda müzikolojik veriye rastlamak mümkündür. Öyle ki onun eserlerine başvurulmadan yazılmış Türk müzik tarihi çalışmaları, yetersiz kabul edilir. Bunların yanı sıra Ögel'in müstakil olarak müzikoloji konulu kitapları ve tebliğleri vardır. Müzik tarihi, organoloji (çalgı bilim), kültürel müzikoloji gibi pek çok alt branşa veri sunan eserleri, bu eserlerin içeriği, ne gibi yenilikler ve öneriler getirdiği, Ögel'in müzikle olan ilişkisinin temeli, bu çalışmanın odaklandığ 1 hususlardır. Çalışmada literatür taraması ile birlikte kendisinin öğrencisi olmuş kıymetli biliminsanlarının görüşlerine de başvurulmuştur ${ }^{1}$.

\section{Ögel'in Hayatı ve Eğitimine Kısa Bir Bakış}

Mehmed Bahaeddin Ögel, 21 Nisan 1923'te Elazığ'ın Çarşı Mahallesi'nde doğmuştur. Babası Harput eşrafindan Mehmed Şemseddin Bey, annesi Nâdire Hanım'dır. İlk ve ortaokulu Elazığ'da, liseyi Malatya’da okumuş; 1941 yılında girdiği Ankara Üniversitesi Dil ve Tarih-Coğrafya Fakültesi Tarih Bölümünden mezun olmuş ve 1945'te Erzurum Lisesinde tarih öğretmeni olarak görevine başlamıştır (Yuvalı, 2007:22). 1948 yılında "Uygur Devleti'nin Kuruluşu” başlıklı tezi ile doktor unvanını almış; Hasanoğlan Köy Enstitüsündeki görevinin ardından, 27 Ekim 1948 tarihinde A.Ü. DTCF Tarih Bölümünde akademisyen olarak göreve başlamıştır (Yuvalı, 1993:7-8).

Yurt içi ve yurt dışında bilimsel çalı̧̧malarda bulunan Profesör Ögel, DTCF'de Genel Türk Tarihi kürsü başkanlığı, A.Ü. Türk İnkılap Tarihi Enstitüsü, İnkılap Tarihi A.B.D. başkanlığı, A.Ü. Atatürk İlkeleri Araştırma ve Uygulama Merkezi ile Osmanlı Tarihi Araştırma ve Uygulama Merkezi başkanlıkları

Yarı yapılandırılmı̧ görüşme formu, çalışmanın devam ettiği dönemde süren Covid-19 salgını nedeniyle telefon görüşmesi şeklinde gerçekleştirilmiştir. İsimleri kaynakça kısmında sunulan birbirinden değerli biliminsanlarına, katkılarından dolayı teşekkürü bir borç bilirim. 
gibi idari görevlerde bulunmuştur (Gündoğdu,1995:321). 1947 yılından, vefat ettiği 1989 yılına kadar 19 kitap yazmış; 122 makale, tebliğ ve konferans gerçekleştirmiştir².

Ögel, yazılı eserleri kadar yetiştirdiği öğrencilerine de önem vermiştir. Buharal, "Merhum hocam insan yetiştirmenin önemi üzerinde durur ve buna "canlı eser verme" derdi" demektedir (Buharal,1995:94). Mütevazı olmakla birlikte ilmin verdiği kuvvetle hep gerçekleri savunmuş; Türk ahlak ve seciyesi ile İstanbul beyefendiliğini kişiliğinde sentezlemiştir (Özçelik,2019:44).

Eylül 1987'de Moğolistan'da bulunduğu sırada rahatsızlanan Bahaeddin Ögel, hastalığının ilerlemesi sonucu 7 Mart 1989 tarihinde vefat etmiştir. Bulduk, kendisinin hastanede ölüm anına kadar Türk tarihi ve kültürü için çalıştığını ifade etmektedir (KK2) ${ }^{3}$.

Prof. Dr. Üçler Bulduk ve Prof. Dr. Ahmet Taşağıl gibi Prof. Dr. Mehmet Altay Köymen de Ögel'in vefatının ardından basının ve yetkililerin ilgisizliğinden söz etmiştir. Türkiye ve Tercüman gazetelerinin dışında onun ölümünden söz edilmediğini ifade eden Köymen, "bu ölüm gerçek ilim adamlarına, özellikle Türk tarihçilerine büyük önem veren Atatürk zamanında gerçekleşseydi, yer yerinden oynardı" diyerek yaşanan vefasızlıktan bahsetmiştir. (Köymen, 1989:62; KK2).

\section{Ögel'in Çok Yönlülüğü ve Kültür Ögelerinin Birliğine Olan İnancı}

Ögel, tarihi besleyen dil, folklor, sanat tarihi, coğrafya ve arkeoloji alanlarında da bir otorite olduğunu eserleriyle ortaya koymuş komple bir tarihçidir (Akçora,1995:122). Alanındaki hâkimiyetinin yanı sıra çok yönlü bir biliminsanı olan Ögel, kültürün bütün ögeleri ile ilgilenmiştir (KK4; KK3). Tarihin kolektif bir bilim dalı olduğunu düşünen Ögel, bilhassa kültür tarihi çalışmalarında disiplinlerarası yaklaşımın önemini fark etmiş ve kendisini çok yönlü bir biliminsanı olarak geliştirmiştir. Farklı ülkelerde, Avrupa'da bulunduğu dönemlerde dahi, Orta Asya Türk tarihi ile ilgili çalı̧̧malar yapan biliminsanları ile yakınlık kurmuş; bu alandaki bilgisini derinleştirmiştir.

Türk milli kültürünü büyük bir titizlikle ele alan Ögel, Türk dili, Türk dini, Türk sanatı, Türk töresi, Türk yaşayışını tarihi seyir içinde değerlendirmiş ve günümüz kültürüyle bağ kurmuştur (Göde,1995:108). Kültürel birlik görü-

Eserler listesi için bkz. Abdullah Gündoğdu, "Prof. Dr. Bahaeddin Ögel", A.Ü.D.T.C.F. Tarih Araștırmaları Dergisi, S.28, 1995, s.321-330; Abdulkadir Yuval, Babaeddin Ögel, Ankara 1993.

Kaynak kişilerin (KK) listesi, Kaynakçada sunulmuştur. 
şünde hem tarihi zincirleri, hem de coğrafya zincirini takip etmiştir. Nitekim, Anadolu ve Orta Asya kültür birliği üzerinde önemle durmuştur (Yuvalı ve Aşan,1995:14).

Farklı disiplinlerde bilgi sahibi olmanın gerekliliği gibi, çok dilli olmanın da yetkin bir biliminsanı için zaruri olduğunu henüz öğrencilik yıllarında anlamıştır. DTCF'de okuduğu dönemde Sinoloji ve Arkeoloji bölümlerinden dersler almış ve bir araştırmacı için gerekli olan diğer dersleri de dışardan takip etmiştir. Çince, Moğolca, Farsça, Rusça gibi kaynak dillerin yanı sıra Fransızca, Almanca, İngilizce gibi Batı dillerini de araştırma yapacak kadar öğrenmiş ve 1945 yllından itibaren Türkçe ve Almanca makaleler yayınlamaya başlamıştır (Yuvalı, 1993:3; Köymen,1989:61). Antropolojide genel olarak bilgilerin derlenmesine dayalı ampirisist yaklaşımlar kümesi ve daha çok epistemolojik kapsamda değerlendirilebilecek olan araştırma ve incelemelerden söz etmek mümkündür (Hassan, 1985: 16). Ögel’in çalışmaları her iki ana yaklaşım tipini de içerir.

Türk dünyası birliğinin, kültürel birlikten geçtiğini düşünen Ögel’in (KK4) Türk Kültür Tarihine Giriş serisi, onun fikir kaynağını ve esasını ortaya koymaktadır (Yuvalı,1993:26). Dr. Yaşar Kalafat'ın da değindiği üzere Ögel'in bu çalışmaları, Türk kültüründe musiki, el sanatları, halk takvimi, spor, beslenme, giyim-kuşam ve benzeri gibi üst başlıkların yanında renk, yön, rüya, fal, eğlence gibi konularda yapılacak çalışmalar için de kaynak eserlerdir (Kalafat,2009:212). Köymen, Ögel'in Türk Tarihine Giriş adlı dokuz ciltlik bu eseri için, "her ciltte ele alınan konu, giriş değil, ta kendisidir" demektedir (Köymen,1995:58).

Ögel, “Türk kültür tarihinde bizden sonraki nesiller için küçük bir $1 ̧ ̧ 1 k$ tutabilirsek bu bizim için büyük mutluluk olacaktır. Tarihçiler bir çağın düşünce ve yaşayış sentezini yaparken, her türlü vesikayı kullanmak zorundadır. Yoksa biz ne bir dilci, ne de sanat tarihçisiyiz. Bu ilimlerin metotları ayrıdır" (Yuvalı ve Aşan,1995:36) diyerek, mütevazı kimliğini gösterse de, Türklüğü var eden kültür unsurlarına duyduğu derin ilgi, bitmek bilmez üretme tutkusu, detaycı ve araştırmacı kişiliğiyle ortaya koyduğu eserler, çoklu/ multidisipliner açıdan son derece kıymetlidir.

Türk tarihine ilişkin eserlerinin yanında, Türk mitolojisi, eski Türk sanatının günümüze yansımalar1 ${ }^{4}$, Türklerde ağaç işçiliği ve mimari detaylar ${ }^{5}$, minyatür

bkz. Erzurum Anıtlarında Eski Altay-Türk Sanatının İzleri, 1947.

bkz. Erzurum Tavan İşlemeleri, Ülkü, Temmuz,1947; Erzurum Evleri, Ülkü, Aralık,1947. 
albümleri üzerine çalışmalar ${ }^{6}$, halk biliminde yöntem ${ }^{7}$, Türklerde ölü gömme âdetleri ${ }^{8}$, başlik sistemi ${ }^{9}$, Türk kültüründe kadının yeri ${ }^{10}$, at kültü ${ }^{11}$, silahçılık, ordu sistemi ${ }^{12}$, yemek kültürü ${ }^{13}$, kyyafetler ve aksesuarlar ${ }^{14}$, ziraat kültürü ${ }^{15}$, köy ve şehir hayat1 ${ }^{16}$, ev kültürü ${ }^{17}$, halıc1lık ${ }^{18}$, tuğ ve bayrak ${ }^{19}$ Ögel'in çalıştığ 1 konular arasındadir.

Çalışmanın devamında da değinildiği üzere Ögel, Türk mitolojisi çalışmalarını çok bilinçli olarak seçmiştir. Mitolojik köklere indikçe, toplumun bilinçaltına inilmiş olacağını düşünmüştür (KK4). Folklor araştırmaları için de onun eserleri son derece mühimdir. Türkdoğan, Ögel'in folklorun milli kültürümüzün en önemli yanını teşkil ettiğini belirttiğini ifade eder (Türkdoğan,1995:79). Yuvalı ve Aşan (1995:30), Ögel'in Türk siyasi, kültür, askeri tarihçileri hatta folklor araştırmaları için çığır açtığından söz ederler. $\mathrm{Bu}$ şüphesiz doğru bir tespittir. Bu durum, folklor alanından daha bağımsız ve özel şekilde müzikoloji için de söz konusudur. Ögel'in bilhassa İslamiyet'ten önceki dönem Türk müzik tarihi konulu eserleri, müzik tarihi uzmanları için temel başvuru ve başucu kaynakları olmuştur.

Musiki aletleri ve mehter hakkındaki bilgileri, bir kültür tarihçisi olarak açıklayan Ögel, eserlerinde daima Türk milletinin başarılarını sadece kılıç kuvveti ile elde etmediğini, kültür ve medeniyetiyle bütün dünyayı aydınlattığını vurgulamıştır (Akçora,1995:121).

\footnotetext{
$6 \quad$ bkz. Topkapı Sarayı Müzesi'nde Bulunan İki Minyatür Albümü Hakkında Notlar,1955; Fatih Albümünde Şeyhi İmzalı Minyatürler,1958.

7 bkz. Türk Halk Bilgisi Araştırmalarında Metod, Mersin Kültür ve Eğitim Sempozyumu 1988; Türk Kültür Tarihinin Araştırma Metodları ve Türk Halk Bilgisi”, S.Ü. Milletlerarası Türk Halk Edebiyatı ve Folkloru Kongresi,1988.

bkz. Barthold'un Türklerde Ölü Gömme Adetleri Hakkındaki Makalesinin Tenkidi, A.Ü.DTCFD,VIL3, 1948.

bkz. Türklerde Kalın ve Başlık, Milletlerarası Türk Folklor Kongresi,1982.

bkz. Türk Ailesinde Kadın, Tercüman,1984.

bkz. At (tarih) maddesi, Türk Ansiklopedisi, C.IV. Ankara,1950.

bkz. Türk Kültür Tarihine Giriş (TKTG), C.VII,1984.

13 bkz. TKTG,C.IV,1978; Türk Mutfağının Gelişmesi ve Türk Tarih Gelenekleri, Türk Mutfağı Sempozyumu,1982; Toy ve Sofra Üzerine, Türk Dünyası Tarih Dergisi,1987.

bkz.TKTG,C.V, Türklerde Giyecek ve Süslenme,1978.

bkz. TKTG,C.II, Türklerde Ziraat Kültürü,1978.

bkz. TKTG,C.I, Türklerde Köy ve Şehir Hayatı,1978.

bkz. TKTG,C.III, Türklerde Ev Kültürü,1978.

bkz. Halıcılık ve Koyunculuk İşleri, I. Milletlerarası Türk Halı Kongresi,1984.

bkz. Tuğ maddesi, İA,1975; TKTG,C.VI, Türklerde Tuğ ve Bayrak,1984.
} 


\section{Ögel ve Türk Müzik Kültürü}

Ögel, bir bölgenin tarihi geçmişini, köklerini yorumlarken, kültür unsurlarının önemli deliller olduğunu düşünür. Müzik de bu kültürel unsurlardan birisidir. Üstelik müzik her zaman, her durumda ve herkes için var olmuş bir sanattır. Dolayısıyla bir toplumun kültürel özellikleri hakkında derin bilgiler barındırabilir. Bu durum bir kültür tarihçisi olarak Bahaeddin Ögel'in müziğe büyük önem vermesine neden olmuştur. Ancak bu konudaki eserlerinin sayısı, derinliği müziğe olan ilgisinin salt bu amaçtan ileri gelmediğini de düşündürmektedir. Çalışmanın bu kısmında, Ögel'in çalışmaları, onun hakkında yazılan yazılar ve kendisini tanıyan, öğrencisi olmuş kişilerle yaptığımız görüşmelerden elde ettiğimiz bilgiler doğrultusunda, müzik ile olan ilgisini irdelemeye gayret ettik.

Ögel'e göre Türk el sanatları, toponomisi ${ }^{20}$, onomastiğ: $i^{21}$, halk oyunları ve folklorunun diğer sahaları ile ilgili çalışmalara ciddi şekilde ağırlık verildiği takdirde, Türk dünyasının çeşitli kesimleri arasındaki saklı kültürel gerçekler ortaya çıkacak, ayrı parçalar görünümü arz eden Türk kültürünün aslında bir bütün olduğu anlaşılacaktır (Seferoğlu,1989:747). Türk dünyasının ortak değerlerinden birisinin müzik olduğu fikri, eserlerinde görülür (KK4). Eserlerinde nicelik ve detay açısından, müziğe diğer kültürel ögelerden daha fazla önem vermiştir. Özçelik (2019:46), Ögel'in tarih ilmini, kültür ve mitolojisini Türklük penceresinden gördüğünü, milli çıkarlar ile bütünsellik açısından ele aldığını vurgular. Milletin yararına olmayan konulara araştırmalarında öncelik vermeyen Ögel, milli çıkarlar ile hafızaya önem vermiştir. Müzik kültürünün araştırılmasına büyük önem vermesi de, kendisinin bu tasavvuru ile örtüşmektedir. Nitekim müzik, bir milletin hafızasını, birlik olma bilincini en canlı şekilde yaşatan kültür ögelerindendir.

Ögel, Türk Kültür Taribine Giriş eserinin yedinci cildinde, musiki tarihinin, Türk topluluklarının, Türk sosyal ve devlet hayatının, dolayısıyla Türk kültür tarihinin bir bölümü olduğunu vurgular. Türk sazlarının ilk şekillerinin tespiti konusunda, bu serinin 9. cildinde ise şöyle demiştir: "Bir Türk kültür tarihçisi olarak bizi ilgilendiren en önemli bir konu da budur” (Ögel,1987c:1).

Ögel ile pek çok kez sohbet ortamında bulunmuş olan Türkdoğan, Ögel'in derin bir müzik bilgisi olduğundan söz eder. (Türkdoğan,1995:79). Gündoğdu da Ögel'in sanat tarihi ve müzik bilgisinden söz etmiştir (KK4). Öyle ki onun

\footnotetext{
$20 \quad$ Yer adlarının, kökenlerinin, anlamlarının, kullanımının ve tipolojisinin incelenmesi

21 Özel adların, özellikle kişi adlarının kökeni, anlamı, gelişiminin araştııılması.
} 
müzik bilgisi, konservatuvar öğrencileri arasında dahi bilinmekte idi. Namık Açıkgöz, konservatuvar müzik bölümü öğrencilerinin Ögel ile oturdukları masalarına gelerek hocaya Türk musikisi ile ilgili sorular sorduğunu aktarır. Bir buçuk saat süren Türk müziği konulu sohbetin sonuna doğru hocanın, "Müzikte bu yiğit ses ve tavır Orta Asya'dan gelir; Kerkük, Urfa, Harput hattını takip eder ve batıya doğru kırılarak devam eder" dediğini ifade etmiştir (Açıkgöz,1995:139).

\section{Ögel'in Müzik Konusundaki Bilgisi ve İlgisinin Temeli Olarak Harput ve Hoyratlar}

Kendisinin Harput ve Harput müziğine olan ilgisini, günümüzde DTCF'de ülkenin en önde gelen tarih profesörleri olan öğrencileri ve diğer kaynaklar şu şekilde aktarmaktadır:

Bahaeddin Ögel'in eserleri üzerine bibliyografik bir makalesi de bulunan Prof. Dr. Abdullah Gündoğdu, Ögel'in Harput'u çok önemli bir kilit taş1 olarak gördüğünü ifade etmiştir. Azerbaycan, Doğu Anadolu, Irak ve Suriye Türkleri arasında Harput'un coğrafi ve kültürel olarak önemli bir konumda olduğunu vurgulayan Ögel için (KK4) Harput müziği de çok önemli bir yer tutmuştur. Yuvalı (1993:39), "kültür sohbetlerinde doğup büyüdüğü muhitin yani Harput'un tesiri altında kaldığı hemen anlaş1lırdı" demektedir. Prof. Dr. Saadettin Gömeç de "Ögel’in çocukluk ve gençlik dönemlerini geçirdiği Harput'un onun üzerinde çok derin izler bıraktığını belirtmiştir. Yönelttiğimiz soruya istinaden ise "bu bölgenin kuvvetli müzik kültürünün, onun müzikle olan bağına neden olmuş olabileceğini” ifade etmiştir (KK3). Prof. Dr. Üçler Bulduk, "Ögel hoca Harput müzik kültüründen söz ederdi. Annesinden dinlediği masal, ninni ve türkülerden bahsederdi” demiştir (KK2). Annesinden özlemle söz ettiği ve ondan çok etkilendiği kaynaklarda sık yer bulur. Yuvalı, Ögel'in tarihe olan merakının küçük yaşlarda annesinin anlatmış olduğu hikâyelerle başladığını ifade ettiğini belirtir (Yuvalı,1993:1). Onun Harput müziğine, hoyratlara olan ilgisi yine pek çok kaynak tarafindan teyit edilmiştir. Prof. Dr. Eşref Buharalı Hocamız, Ögel'in bilhassa Kerkük hoyratlarını sevdiğini, 1981 yılında kendisinden A. Küzecioğlu'nun kasetini istediğini belirtmiştir (KK1).

Akçora kendisinin müzik sevgi ve ilgisini şu şekilde anlatmıştır: "Öncelikle doğum yeri olan Harput sevgisini, Harput musikisi ile daima açığa vurur; herkese anlatmaya çalışırdı. Elazığ bölgesinin türkülerini sevdiğinden zaman zaman da dinlemeyi çok arzu ederdi. (Akçora, 1995:123). Onun Harput 
müziği ve Güneydoğu Anadolu ile Kerkük hoyratlarına yönelik ilgisi, salt sevgiden daha öteye gitmiştir. Ezgilerdeki benzerlik ve farklılığı bir müzikolog dikkati ile incelemiştir. Ögel (1987b), Harput'ta hepsi gazel tarzında üç üslupta söylenen muhalif ezgi tespit etmiştir. Şehirdeki medreseler ile köylerdeki geleneklerin farklı olmasının, bu üslup değişimlerine neden olabileceğini belirtir. Medrese ve tekkelerde güftelerin de daha ağır olduğunu ifade eder.

Ögel’e göre eski Harput'ta yüksek divan musikisi vardı. Medreselerin etkisiyle oluşmuş, çeşitli Türk kültür çevrelerinin bu musikinin oluşmasında büyük etkisi söz konusuydu. Divanın Güney ve Doğu Anadolu'da çok yaygın bir musiki temeli olduğunu; bu türün İstanbul'dan Güneydoğu Anadolu’ya değil, Anadolu'dan İstanbul'a geçtiğini; Anadolu temelli olduğunu düşündüğünü ifade eder (Ögel,1987b:32-33).

Nakip, Ögel’in Türk Halk Musikisini çok iyi bildiğini, Kerkük, Şanlıurfa, Diyarbakır, Elazığ'da yaygın olan hoyrat havalarını rahatlıkla birbirinden ayırt edebildiğini belirtmiştir. Bahaeddin Ögel müzikologların bu alana eğilmelerini istemiştir. Nitekim Nakip, Ögel'in müzikle çok ilgili olduğunu, kendisini Kerkük ve Anadolu türküleri üzerine çalışmaya teşvik ettiğini aktarmaktadır (Nakip,1995:128).

“Türk Halk Bilgisi Araştırmalarında Tarihi Metod” başlıklı çalışmasında Ögel, kilim ve halıların derin anlamlarından söz ederken bir Harput türküsünü örnek olarak sunar:

"Aş yedim, dilim yandı, döküldü kilim yandı

Ben kilimi aramam, içinde gülüm yandı” (Yuvalı ve Aşan,1995:150)

\section{Üzerinde Çalışmalar Yaptığı ve/veya İlgi Duyduğu Müzik Türleri}

Sadece hoyratlar değil, Türk halk müziği ürünleri, Türk sanat müziği ve mehter müziği, Ögel'in ilgi alanları içinde yer almıştır. Buharalı, onun mehter müziğine meraklı olduğunu ifade etmiştir (KK1). Nitekim, TKTG serisinde yer alan “Türklerde Devlet ve Ordu Mehteri” isimli kitabı, "Türkiye Selçuklularında Devlet ve Ordu Mehteri” başlıklı makalesi, tuğ, nevbet, mehter teşkilatları ile ilgili bilgilerin yanı sıra, Türklerde askeri müzik, bu müziğin görevleri ve askeri müzik çalgılarına yönelik detaylı bilgiler barındırır.

Eserlerinde halk müziğinden sıkça söz eder. Çalgı bilimine sunduğu katk1lar kısmında değinildiği üzere halk müziği çalgılarının kökenleri, etkileşimi, yapıs1, Türk kültürü analizlerinde önemli bir yer tutmuştur. Bilhassa TKTG serisindeki “Türk Halk Musiki Aletleri”, organoloji ve Türk müzik kültürü çalışan biliminsanlarının vazgeçilmez başucu kaynağıdır. 
Ögel, geçmiş dönemlerde halk müziği ile dîni müziğin içiçeliğini vurgular. Eren, abdal ve dervişlerin Osmanlı Devletinin kuruluşunda musiki, ilahi ve şiirleri ile halk için halk ile beraber olduklarını ifade eder. Gerek Bektaşi tekkeleri, gerekse Mevlevi tekkelerindeki musiki ve geleneğin Türk kökenlerini vurgular. Osmanlida İstanbul tekke musikisi ile Anadolu'nun uzak bölgelerindeki medrese, tekke, cami ve derviş musikilerinin farkll1ık gösterebildiğini belirtir. Buralarda İstanbul'dakinin aksine, halk müziği ve dîni müzik arasında bir uçurumun olmadığını ifade eder (Ögel, 1987a:202-204). Bu durumun, Osmanlı'da halk uleması ile İstanbul ulemasının anlaşamamalarına benzediğini; Anadolu halk müziği araştırmalarında, halk ve dîni musikinin yakınlığının göz ardı edilmemesi gerektiğini ifade etmektedir. Nitekim Ögel, eski Türk kitlelerinin musikisini halk musikisi ve dîni musiki diye ayırmanın yanlış olduğunu düşünmektedir. Ona göre bu iki tür, uzun süre iç içedir. Ögel'in eserlerinde eski Türk inancının uluları olan kamların çalgı ve müziklerine ilişkin bilgiler de yer alır.

Akçora Ögel'in Türk sanat musikisini, makamlarını ve çeşitlerini çok iyi bildiğini, duyduğu bir eserin makamını hemen çıkartarak hakkında malumatlar verdiğini aktarmaktadır. (Akçora,1995:123). Prof. Dr. Üçler Bulduk Hocamız da Ögel'in notları arasında müzik notalarını da gördüğünü ifade etmiştir (KK2).

Bu müzik türlerine karşı yoğun ilgisiyle birlikte, popüler müzik ile de ilgilenmiştir. Buna yönelik sorduğumuz bir soruya Eşref Hocamız, "Sezen Aksu'dan da söz ederdi” diye yanıt vermiştir (KK1).

Ögel'in övgüyle söz ettiği müzik nazariyatçıları ve müzisyenler arasında başta, Türk-İslam dünyasının en önemli müzik bilginlerinden olan Abdülkadir Merâgi ve Azerbaycan müziğinin önemli müzisyeni, bestekârı ve bilimadamı Üzeyir Hacıbeyli gelmektedir. Ayrıca Fahrettin Ergeç'ten övgü ile söz ederek, onun bir makam ustası olduğunu ifade eden Ögel, Celal Güzelses'in de hoyrat okuyuşundan bahsetmiştir (KK1).

\section{Müzikoloji Konusundaki Görüşleri}

Ögel “Türk Müziği Araştırmaları ve Türk Kültür Tarihi” başlıklı bildirisinde, Türkiye'de müzikoloji araştırmalarının, Atatürk'ün himaye ve teşvikleriyle başladığını ancak tarih ve dil araştırmaları ile kıyaslandığında pek ileriye gidilmediğini vurgulamaktadır. Müzik çalışmalarının icra ve derleme açısından ilerleme gösterdiğini, müzikolojik araştırmaların ise hem sayıca eksik hem de bazılarının içerik açısından yanlış ve yanlı olduğunu ifade etmektedir. 
Ögel, günümüzde Türk müzikoloji dünyasında önemli hale gelen bir sorunu 1987 yılında fark ederek, uyarı yapmışır. Tebliğinde, müzikolojik araştırmalarda, Anadolu müziğinin birliğine ve dolayısıyla Anadolu kültürüne yönelik yapilan sözde ve yanlı çalışmalardan, adaptelerden bahseder. Bunların propaganda niteliğinde, tehlikeli ve art niyetli çabalar olduğunu vurgular (Ögel,1987a:201). Burada söz edilen Anadolu'nun çeşitli bölgelerindeki müziklerin farklılıklarını yok saymak değildir. Bu farklılıklar şüphesiz en önemli zenginliklerimizdir. Ancak sözde müzikolojik çalışmaların, birlik ve bütünlüğe kasteden amaçlarının olması, son derece art niyetlidir. Prof. Dr. Ögel de bu tehlikeyi fark ederek, bir vatansever olarak uyarısını yapmıştır. Onun bu uyarısı, müzikolojik araştırmaları takip ettiğini, gidişatı konusunda düşündüğünü göstermektedir.

Bahaeddin Ögel, müzikolojik çalışmalardaki eksikliklerin, kompozitörlerin de işlerini zorlaştırdığını vurgulamıştır. Müzik araştırmalarını, uluslararası kültür savaşının bir arac1, aleti olarak gördüğünü ifade etmesi (Ögel,1987a:201), onun müzik çalı̧̧malarına bu kadar önem vermesinin bir açıklamasıdır.

İçel Kültürü’nde yayınlanan “Türk Halk Bilgisi Araştırmalarında Tarihi Metod” isimli yazısında Ögel, İsveç'te yapılmış Tunceli türküleri ile ilgili "Hetredox Türk Halk Musikisi” adlı kaseti eleştirmiştir. Hetredoksun mevcut düzene, mevcut dîni inanışlara aykırı inanç demek olduğunu ifade ederek, Tunceli dedelerinin, halkının inancının Müslümanlık harici bir inanış gibi belirtilmesine karşı çıkar. Müslümanların babası olarak nitelendirilen Ahmet Yesevi'nin bugün Tuncelide pek çok makamı olduğunu, dolaysıyla Tunceli inanışının ve müziklerinin Heteredoks olarak ifadesinin yanlışlı̆̆ını vurgular. Bu durumu cehalet hatta kasıt olarak yorumlar (Yuvalı ve Aşan,1995:48).

Ögel, sadece son 300 yılda İstanbul'da icra edilen musikiyi esas alıp, Türk musikisi nazariyatının yazılmasını da hatalı bulmaktaydı (Nakip,1995:129). Osman1 müesseselerinin, Anadolu müesseselerine dayandığını, müzikal aktarımda da bunun varlığını çeşitli çalışmalarında vurgulamıştır. Anadolu, bilhassa Doğu ve Güneydoğu Anadolu'nun İstanbul müzik kültürünü beslediğini ifade etmiştir. Ögel'in Anadolu'dan İstanbul'a yayılan Türk musikisi görüşüne yönelik olarak Köksal, bir televizyon programinda sunucunun, "Türk musikisi İstanbul'dan fersah fersah ötede, taa Urfa, Diyarbakır illerimize kadar yayılmıştır” demesine çok sinirlendiğini, Türk kültürünün İstanbul'dan oralara değil, oralardan İstanbul'a yayıldığını ifade ettiğini belirtmiştir (Köksal,1995:144-145). Ögel çalışmalarında Anadolu'daki yaylacı ve hayvancı Türklerin arı kalmış müziklerine ve çalgılarına vurgu yapmıştır. 


\section{Müzik Teorisi Konusundaki Bilgisi}

Ögel, halk müziği makam dizilerinin bir bölümünün özelliklerini boy ve kabilelerden aldığını; sonradan ticari, kültürel temaslarla bir bütünleşmeye gidildiğini düşünmektedir (Ögel, 1987a:204). Makam dizileri üzerine olan düşünceleri, onun müzik tarihi ve kültürü ile birlikte nazari kısmına da ilgi duyduğunu göstermektedir.

“Kerkük Halk Musikisi ve Güneydoğu Anadolu” adlı tebliğinde Ögel, Kerkük ve Irak Türklerinden derlenmiş muhalif makam dizisinin, Urfa, Diyarbakır ve Elazığ'da kullanılan makam dizisi olan benzerliğini ve dolayısıyla kültür bağını vurgular. Bu çalışmasında bir kez daha müziği, kültür ve tarih birliğini ortaya koyan bir araç olarak kullanmaktadır.

Ögel, Abdulvahit Küzeci’nin söylediği bir halk ezgisi ile Diyarbakırlı Celal Bey'in söylediği muhalif ezginin benzerliğini vurgular. Bu makam dizisinin Kerkük ve Güneydoğu Anadolu'daki yaygın kullanımının kültür birliğine işaret olduğunu ifade eder.

Muhalif makam dizisinde yazılmı̧̧ olan "Çayırı Bıçakladım” adlı bir şarkının, hüzzam olarak sunulmasının yanlışlı̆̆ını belirtir (Ögel,1987b:32).

Akçora Ögel için "bir eserin acem aşiran, şehnaz, ferehnak veya sultan-1 yegah makamından hangisine ait olduğunu hemen çıkarır ve izahatlar verirdi” demektedir (Akçora, 1995:123).

\section{Müzik Tarihinde izlediği Yol ve Müzikoloji Yazımına Katkılanı}

Ögel, Türk medeniyetinin kesintisiz devamını müzik kültürü için de düşünmüştür. Türk tarihini ve dolayısıyla Türk müzik tarihini her zaman bir bütün olarak ele almıştır.

Orta Asya Türk tarihi gibi Orta Asya Türk müziğini çalışanlar için de en büyük sorunlar, incelenen coğrafyanın genişliği ve belgelerin azlığıdır. Bunlarla birlikte kadim Türk topraklarının Rusya (Ögel'in döneminde SSCB) ve Çin'in elinde bulunması, bu bölgelerde araştırma yapmanın, bürokratik engeller nedeniyle çok zor olması bir başka sıkıntıdır. Rusya'da günümüzde daha yumuşamış bir politika varken, Çin hâlâ araştırmacılar için zorlu bir bölgedir.

Çin'de araştırma yapmak isteyen Ögel de bürokratik engellere takılmış ancak yılmayarak bölgeye gitmiş ve burada 3 yıl kalmış, Çincesini geliştirerek böl- 
geyi tanımış, araştırmalar yapmıştır. SSCB, Doğu ve Batı Türkistan ve diğer seyahatleri, onun Türk coğrafyasındaki durumu görerek, geçmişe dönük ç1karımlar yapmasına olanak tanımıştır (Yuvalı,1993:25). Nitekim Gündoğdu, Ögel'in "malumatın çok olduğu dönemlerden, malumatın az olduğu döneme ulaşma çabası içinde olduğunu" ifade etmiştir. Türk müzik tarihinin geçmiş dönemlerine ilişkin çıkarımlarında da aynı yolu izlemiştir (KK4). Ögel'in müzik tarihi için malumatın çok olduğu dönemlerden, verilerin az olduğu dönemlere doğru uzanan kademeli görüş ve tahminleri kadar, çalgıların ve müzik türlerinin coğrafi yayılımı konusundaki görüşleri de son derece önemlidir.

Çıkarımlar yaptığında bile buna ilişkin kanıtlarını ve delillerini sunmuştur. Nitekim elde vesika olmadan yazmanın ve fikir beyan etmenin doğru olmayacağını savunmuştur (Özçelik, 2019:48). Onun bu yaklaşımı, bilimsel müzikoloji yazımı için örnek teşkil etmiştir.

Ögel’in çalışmalarında izlediği yollardan birisi, materyallerin sınıflandırılması yoluyla sonuçlara varmadır (Yuvalı ve Aşan,1995:34). Müzik tarihi ve kültürel müzikoloji verilerinde de bu yola sık sık başvurmuştur.

Üzerinde durduğu bir başka konu ise Türk kültürünün bölünmez parçası olan Türk müziğinin Osmanlı ve İstanbul kültüründen ibaret olmadığının kavranması gerektiğidir (Ögel, 1987a:201). Türk müzik tarihi çalı̧̧alarında dikkat edilmesi gereken en önemli hususun, Osmanlı Devletinden önceki dönemlerin göz ardı edilmemesi olduğunu pek çok kez yinelemiştir. Onun Osmanlı'dan önce de Türk tarihinin varlığını, kültürünün haşmetini kabul ettirmek için ortaya koyduğu çabalarda müzik kültürünün ayrıcalıklı bir konumu vardır. Son yıllarda nispeten Osmanlı öncesi Türk müzik tarihine yönelik çalışmalar artmaya başlamış olsa da, Ögel’in söz ettiği dönemlerde bu durum büyük bir problemdi. Kendisinin çalışmaları ve teşvikleri, biliminsanlarını bu konuya yöneltmiştir. Yapılan çalışmalar büyük ölçüde Ögel’in çalışmalarından faydalanılarak oluşturulmuştur.

Ona göre Türk müzik tarihinde "genetik metot” uygulanmalıdır. Köprülü’nün Anadolu Türklüğünü Horosan ile bağdaştırmasını örnek olarak gösterir ve kültür kuruluşlarının geçmiş dönemlerden günümüze birbirinin devamı olarak geldiğinin göz ardı edilmemesi gerektiğini ifade eder (Ögel,1987a:202). Buna göre Türk müzik tarihi araştırmalarında da birbirini takip eden süreç ve geçmiş dönemler dikkate alınmalıdır. 


\section{Türk Çalgılarına Yönelik Çalışmalarının İçeriği}

Ögel her ne kadar çalgı sınıflaması konusunda genel bir değerlendirme yapmamış ise de, ele aldığı bölgelerdeki çalgıları çalınış biçimleri açısından (yaylı, tezeneli vb.) alt başlıklara ayırmıştır. Bunlarla birlikte çalgıları dış tesirlerden uzak olan Türk kültür çevrelerinde gelişenler ve diş tesirlerden etkilenenler olarak da tanımladığı, bu çalgılara ilişkin bilgiler ve çizimler sunduğu görülür. Çalgıların tel sayılarından söz eder ve tel sayılarına göre (dutar, setar vb.) isimlendirilmelerine açıllık getirir.

Çalgıların kullanıldıkları ortam ve toplum tarafindan çalgılara yüklenen anlamların, felsefi değerler taşıyabildiğini düşünen Ögel, TKTG eserinin 7. cildinde, davul ve zurna üzerinden buna bir açıklama getirir: "Davul ve zurna birer meydan sazı idiler. Meydan ise halkın istekle ve koşarak geldiği, şen ve şenlik içinde yaşadığı bir yerdir. Böylece davul ve zurna halkı birbirine kaynaştıran; birlik, beraberlik ve dayanışma içinde halkı (etkinliğe) hazırlayan; halkı müşterek istek ve dileklerle yöneten, kutlu bir alet ve aracı rolünü üstlenmektedir" demektedir. Davul ve zurna, Türk kültürünün imzası olarak Balkanlar'da dahi canlı şekilde yaşamaktadır (Göher Vural,2017:295). Ögel, çalışmalarında pek çok kez davulun hükümdarlık alameti olmasından bahseder. Sancak ve mehterin ayrılmazlığını vurgular. Onun eserlerinde çalgılara yüklenen felsefi anlamlar, yan anlamsal görünümler sık sık ele alınır.

Ögel'in eserlerinde Türk sazlarının kökenleri konusunda bilgiler bulmak mümkündür. (Örneğin 1987c:63-69). Çalgıların geçmişten günümüze geçirdiği değişimler, diş tesirler nedeniyle değişim geçirmiş çalgılar ya da diş tesirlerden uzak çalgılar eserlerinde işlenen konulardan bir diğeridir. Farklı boyların, devletlerin kullandıkları çalgıların ayrı ayrı sunumu ve tüm Türk dünyası için ortak yönlerinin ifadesi eserlerinde yer alır.

Eserlerinde çalgıların yapısına ilişkin bilgiler vardır. Çalgı yapımında kullanılan ağaçlar, tel yapımında kullanılan maddeler gibi bilgiler Ögel'in eserlerinde yer alır. Bu malzeme kullanımının varsa mitolojik temellerinden detaylı şekilde söz edilir. Ayrıca çalgının temel biçiminin yanı sıra perdeli ya da perdesiz oluşu, kaç perdeden oluştuğu, akordları gibi detaylara da girilmiştir. Çalg1ların görünümlerine ilişkin farklı kaynaklara dayanan çizimler, organoloji çalı̧̧anlar için yol göstericidir. Müzikli sahneler, çalgılara ilişkin çok sayıda minyatür ve çizimin kitaplarında yer alması, Ögel'in eserlerini müzikolojik açıdan daha da önemli bir konuma yükseltir. Ögel bu resimleri, büyük bir titizlikle ve müzikolojik hassasiyet ile yorumlamıştır. 


\section{Müzikal Terimler Konusundaki Çalışmaları}

Türk dünyasında karşılığı olan ancak Anadolu Türklerince pek fazla bilinmeyen müzikal kelimelerin tanıtımı (ötme, ökleme, sağu, ölöng, külegeç, küy vb.) ve içeriklerinin anlatımı Ögel'in eserlerinde yer alır. Ögel çalışmalarında, üzerinde tartışma bulunan müzikal kelimeler (ezgi, kökleme vb.) üzerine tanımlama ve tartışmalar da gerçekleştirmiştir. Ayrıca çalgı adlarının etimolojik kökenine, değişimine ilişkin bilgiler de Ögel’in eserlerinde görülür. TKTG 9 ciltte kaleme aldığı “Ozan Sözlüğü” ve “Türk, Ses, Melodi ve Musiki Sözlügü̈ ile pek çok terime açıklık getirmiştir.

\section{Müziğin İşlevlerine Yönelik Görüşleri}

Türk musikisinin yalnızca şenlik, eğlence ve ibadete mahsus olmadığını; siyasi, askerî ve pek çok sosyal etkinlik aracı olarak kullanıldığını örnekleriyle anlatır. Bunlarla birlikte müziğin milli kimliği taşıma ve aktarma işlevini son derece önemsemiştir.

\section{Türk Müziği ve Türk Mitolojisi Konulu Çalışmaları ve Görüşleri}

Türk mitolojisi, Türk sanatı gibi kavramları bilimsel ortamda oturtmaya gayret etmiş olan Ögel, bir milletin yaratıcı enerjisini mitolojide görmüştür. Mitolojik köklere indikçe, toplumun bilinçaltına inmiş olunduğunu düşünen Ögel, Gündoğdu'nun ifadesine göre, "mitlerde toplumun enerjisini bulmak mümkündür” demiştir (KK4). Bu doğrultuda Türk mitolojisi ile Türk müzikolojisi arasında bağ kuran ilk bilinçli çalışmaların da Ögel tarafindan yapıldı̆̆1 ifade edilebilir.

Çalgıların yaratılış efsaneleri; çalgıların yapıldığı ağaçların, derilerin, tellerin vb. kutsiyeti ve Türk mitolojisinde bu parçaların yeri; çalgı parçalarındaki renk tercihinin Türk mitolojisi ile olan bağları (kopuzun siyah-beyaz kılları gibi); efsanelerde müzik, müzisyen ve çalgılar, Ögel'in eserlerinde yer alan bilgilerdendir. O bu bilgileri sunarken bir yandan da Türk kültürünün müziğge ve çalgılara verdiği önemi, toplumun bilinçaltında müziğin kuvvetli yerini vurgulamaktadir.

\section{Müzik Yeteneği}

Yaptı̆̆ımız görüşmelerde kendisinin herhangi bir çalgı çaldığına ilişkin bilgi edinmedik. Bununla birlikte çok iyi bir dinleyici olduğu pek çok kez ifade edildi. Ayrıca, bir insanın doğru entonasyonla şarkı söylemesi ve/veya ıslık 
çalmasının müzik yeteneği belirtilerinden birisi olduğundan yola çıkıldığında, aşağıdaki ifadeler, kendisinin müzik yeteneği olduğunu düşündürmektedir:

Hikmet Büyüklimanl, Ögel hocanın müzik kulağının varlı̆̆ını gösteren, iyi entonasyonlu 1slık çalı̧̧ için şöyle demektedir: "Çok yakınlarının bildiği üzere, 1slıkla çok güzel ney çalma meziyeti, biraraya geldiğimizde devamlı kendisini dinlememiz için ricacı olmamıza sebep olurdu. $\mathrm{O}$, mütevazı kişiliği ile hiçbirimizi kırmazdı" demektedir (Büyüklimanl,1995:73). Görüşme gerçekleştirdiğimiz Prof. Dr. Eşref Buharalı da bu bilgiyi doğrulamıştır. İfadesine göre, Ankara Devlet Konservatuvarı ile Niğde Üniversitesi’nde çalışmı̧̧ olan değerli müzik adamı, akademisyen ve müzik eğitimcisi Prof. Muzaffer Arkan'ın Buharalı'ya "Bahaeddin Ögel'in sslık ile müzik çalışını duydun mu? Eserleri çok güzel terennüm ediyor” demesi (KK1), iyi bir müzisyenin kulağ1 ile de Ögel'in müzik kulağının onaylandığını göstermektedir. 


\section{SONUÇ}

Bahaeddin Ögel, tarihi besleyen kültür ögelerinin bir bütünü oluşturduğu düşüncesiyle, müzik, dil, folklor, sanat tarihi, coğrafya ve arkeoloji gibi alanlardan istifade etmiştir. Ögel, tarihe yardımcı bu alanları sadece tarihi yorumlamada kullanmamış; doğrudan bu dallarda başat eser olarak kabul edilen çalı̧̧malar ortaya koymuştur. Bilhassa müzik konusundaki bilgisi ve ilgisi Ögel’in müzikoloji alanına büyük katkılar sunan eserlerini kaleme almas1nı sağlamıştır. Müziğin bir toplumun kültür taşlarından birisi olduğunu, bu konuda çalışacak vatansever biliminsanlarının yetişmesi gerektiğini vurgulamış; kendisi de bir etnomüzikoloğa yakışır biçimde titiz araştırmalar gerçekleştirmiştir. Bahaeddin Ögel’in müzik tarihi ve kültürel müzikoloji dallarına katkılarını, eserlerin türü ve boyutuna göre, ikiye ayırmak mümkündür. İlki, temelde Türk tarihi ve mitolojisi konulu olan ancak içerisinde müzikolojik veriler barındıran eserler; diğeri ise doğrudan Türk müziği ile ilgili müstakil eserlerdir. Buna yönelik olarak aşağıdaki tablo sunulmuştur:

\section{Tablo 1. Bahaeddin Ögel'in Müzikolojik Bilgiler Barındıran Eserleri}
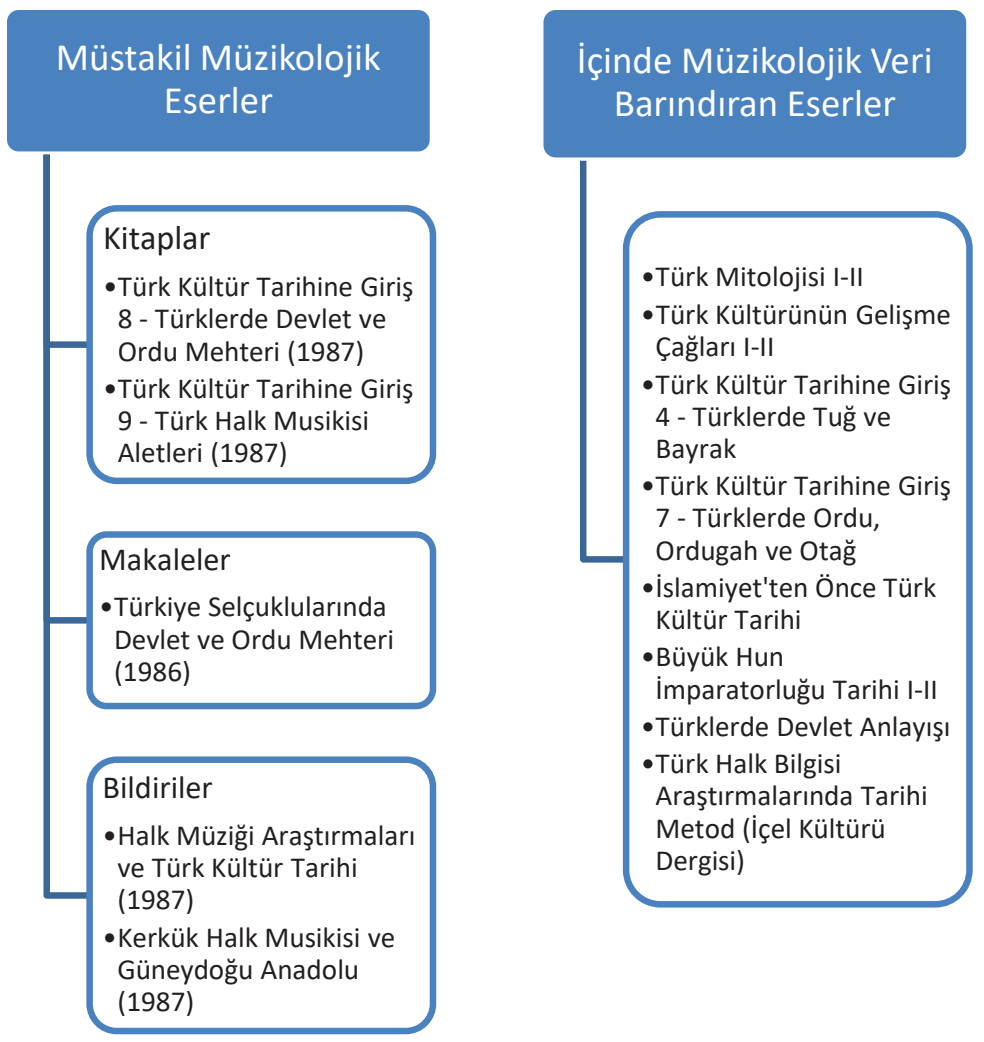
Tabloda sunulduğu üzere Ögel'in TKTG dizisinden 9 numaraları kitabı doğrudan Türk halk müziği çalgıları üzerinedir. Çalgıların yapısı, coğrafi dağllımı, isimlerinin etimolojik kökenleri gibi pek çok hususun detaylı şekilde ele alındığı bu çalışmanın yanı sıra, serinin 8. kitabı da Türk askerî müziği üzerinedir. Bu çalışmalardan bir y1l önce, Selçuklu döneminde askerî müzik konulu makalesi, Selçuklu Araştırmaları Dergisinin 1. sayısında yayınlanmıştır. Irak Türkleri Sempozyumunda sunduğu "Kerkük Halk Musikisi ve Güneydoğu Anadolu” isimli tebliği ile III. Milletlerarası Türk Folklor Kongresinde sunduğu "Halk Müziği Araştırmaları ve Türk Kültür Tarihi” isimli tebliği 1987 yılında yayınlanmıştır. Tablonun sağ sütununda ise Ögel’in Türk kültür ve tarihine yönelik olan ancak içlerinde Türk müziğine ilişkin bilgiler barındıran eserleri görülmektedir.

Bahaeddin Ögel'in Tablo 1'de sunulan eserlerin müzikolojinin hangi alt dallarına veya hangi şekilde veri sunduğu ise Tablo 2'de işlenmiştir. Aşağıda görüleceği üzere, tabloda ilk sırada müzik tarihine değinilmiştir. Bir Türk tarihi uzmanı olan Ögel, doğal olarak değindiği olay ve olguları kronolojik bir bakış açısı ile açıklamıştır. Bilhassa İslamiyet’ten önce Türk müziği konulu çalışmalarda var olan kaynak sorunu, Ögel sayesinde önemli ölçüde azalmıştır. Türk müzik tarihi konulu araştırmalar, veri yetersizliği, coğrafi alanın büyüklüğü ve dağınıklığı gibi nedenlerden dolayı oldukça sınırlıdır. Ögel, bu araştırmaların başlıca dayanak noktası olmuştur.

Eserlerinde başta halk müziği ve askerî müzik olmak üzere farklı müzik türlerine değinmiştir. Bunlar içinde sanat müziği (Uygurlarda saray musikisi gibi), dîni musiki (tekke musikisi, kam müziği, Budist müzik vb.) sayılabilir.

Ögel'in müzikolojiye sunduğu en büyük katkılardan bir diğeri ise şüphesiz organoloji yani çalgıbilimine sunduğu çok yönlü verilerdir. Organoloji, çalgıların tarihi, isimlendirilişi, sınıflandırılışı, yapısı, gelişimi gibi özellikleri ile ilgilenen bir daldır. Bahaeddin Ögel bu hususların hepsi için değerli bilgiler aktarmaktadır.

Vesikalara dayalı bilgi sunumu, bilinenden bilinmeyene gitme, tarihi ve coğrafi zincirleri takip, disiplinlerarası yaklaşım gibi araştırma ve yazım yöntemleri ile müzikoloji bilimine büyük katkılar sunmuştur. 


\section{Tablo 2. Bahaeddin Ögel’in Müzikolojiye Sunduğu Katkılar}

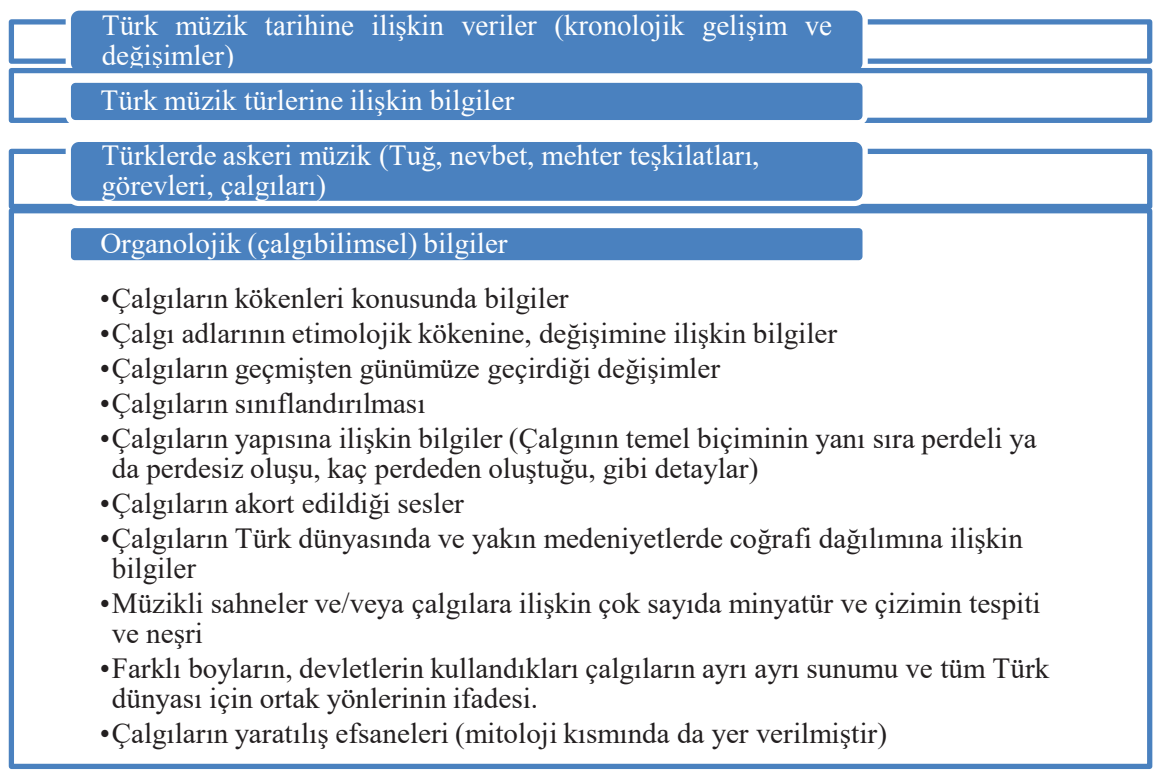

Müzik ve mitoloji konulu bilgiler

- Çalgııların yaratılış efsaneleri

- Çalgıların yapıldığı ağaçların, derilerin, tellerin vb. kutsiyeti ve Türk mitolojisinde bu parçaların yeri

- Çalgı parçalarındaki renk tercihinin Türk mitolojisi ile olan bağları

•Efsanelerde müzik, müzisyen ve çalgılar

\section{Müzik ile ilişskili kelimelere yönelik bilgiler}

•Çalgı isimlerinin etimolojik kökenleri (organoloji kısmında da yer verilmiştir)

- Üzerinde tartışma bulunan müzikal kelimeler konusunda tanımlama ve tartışmalar (ezgi, kökleme vb)

-Türk dünyasında karșıllığı olan ancak Anadolu Türklerince pek fazla bilinmeyen müzikal kelimelerin tanıtımı (ötme, ökleme, sağu, ölöng, külegeç, küy vb.) ve içeriklerinin anlatımı

-Aynı isimli bir çalgının farklı Türk topluluklarında aldığı isimsel ya da biçimsel farkl11ıkların tespiti

\section{Müzikoloji Anlayışına ve Yazımına Sunduğu Katkılar}

-Belgelere dayalı bilgi sunumu

-Bilinen dönemden bilinmeyene bilimsel çıkarımlar

-Tarihi ve coğrafi zincileri takip

-Disiplinlerarası yaklaşımın önemi

-Mitoloji ve müzikolojinin temas noktalarını tespit

•Milli müzikoloji çalışmalarının öneminin vurgulanması 


\section{KAYNAKLAR}

Açıkgöz, Namık (1995). "Bir Kültür Dervişi”, Prof. Dr. Bahaeddin Ögel, İstanbul: Türk Dünyası Araştırmaları Vakfi, s.138-140.

Akçora, Ergünöz (1995). "Vefatının Üçüncü Yılında Çeşitli Yönleriyle Bahaeddin Ögel”, Prof. Dr. Bahaeddin Ögel, İstanbul:Türk Dünyası Araştırmaları Vakfi, s.116-127.

Buharal, Eşref (1995). "Merhun Hocam Bahaeddin Ögel'in Ardından”, Prof. Dr. Bahaeddin Ögel, İstanbul:Türk Dünyası Araştırmaları Vakfi, s.93-96.

Büyüklimanl, Hikmet (1995). "Hocam Prof. Dr. Bahaeddin Ögel”, Prof. Dr. Bahaeddin Ögel, İstanbul: Türk Dünyası Araştırmaları Vakfi, s.72-75.

Göde, Kemal (1995). "Harput'tan Ötüken'”, Prof. Dr. Babaeddin Ögel, İstanbul: Türk Dünyası Araştırmaları Vakfi, s.108.

Gündoğdu, Abdullah (1995). “Prof. Dr. Bahaeddin Ögel”, A.Ü.D.T.C.F. Tarih Araștırmalar Dergisi 28, s.321-330.

Hassan, Ümit (1985). Eski Türk Toplumu Üzerine İncelemeler, İstanbul: Kaynak Yayınları.

Kalafat, Yaşar (2009). "Yaşayan Eski Türk İnançları İtibariyle "Türk Mitolojisi” ve Prof. Dr. Bahaeddin Ögel”, Uluslararası Sosyal Araştırmalar Dergisi 2/8, s.212-220.

Köksal, Hasan (1995). “Az ve Öz”, Prof. Dr. Bahaeddin Ögel, İstanbul: Türk Dünyası Araştırmaları Vakfi, s.144-145.

Köymen, Mehmet Altay (1989). "Prof. Dr. Bahaeddin Ögel'in Vefatı Münasebetiyle Bazı Düşünceler”, Türk Dünyası Tarih Dergisi 29, s.61-62.

Köymen, Mehmet Altay (1995). “Prof. Dr. Bahaeddin Ögel’in Kişiliği, Eserleri ve Fikirleri”, Prof. Dr. Bahaeddin Ögel, İstanbul: Türk Dünyası Araştırmalar1 Vakfi, s.54-61.

Nakip, Mahir (1995). "Bahaeddin Ögel ve Türk Musikisi”, Prof. Dr. Bahaeddin Ögel, İstanbul: Türk Dünyası Araştırmaları Vakfı, s.128-131.

Ögel, Bahaeddin (1987a). "Türk Müziği Araştırmaları ve Türk Kültür Tarihi”, III. Milletlerarası Türk Folklor Kongresi Bildirileri, C.III., Ankara: Başbakanlık Basımevi, s.201-204.

Ögel, Bahaeddin (1987b). "Kerkük Halk Musikisi ve Güneydoğu Anadolu” Irak Türkleri Sempozyumu Tebliğleri, Haz.M.Nakip ve Z.Köprülü, Ankara: Gazi Üniversitesi, Yayınları. 
Ögel, Bahaeddin (1987c). Türk Kültür Taribine Giriş-Türk Halk Musikisi Aletleri, C.9, Ankara: Kültür Bakanlığ1 Yayınları.

Özçelik, İsmail (2019). "Dersleri ve Eserleri Işı̆̆ında Büyük Türk Tarihçisi Prof. Dr. Bahaeddin Ögel'in Tarih Tasavvuru ve Metodolojisi”, Türk Tarihi Araştırmaları Dergisi 4/1, s.40-58.

Seferoğlu, Ş. Kaya (1989). "Hocam Bahaeddin Ögel”, Türk Kültürü XXVII/320, s.745-757.

Türkdoğan, Orhan (1995). "Ögel'i Anarken”, Prof. Dr. Bahaeddin Ögel, İstanbul: Türk Dünyası Araştırmaları Vakfı, s.78-81.

Vural Göher, Feyzan (2017), "Kökenlerinden Günümüze Türk ve Makedon Düğünlerinde Davul-Zurna ile Tapan-Zurla”, TÜBAR XLII, s.273-298.

Yuvalı, Abdülkadir (1993). Bahaeddin Ögel, Ankara: Kültür Bakanlığı Yayınlar1.

Yuvalı, Abdülkadir (2007). "Bahaeddin Ögel” mad., İA, C.34, İstanbul, s.2223.

Yuvalı, Abdülkadir ve Muhammet Beşir Aşan (1995). Prof. Dr. Bahaeddin Ögel, İstanbul: Türk Dünyası Araştırmaları Vakfı.

Kaynak Kişiler Listesi (Yaş Sıralamasıyla)

KK1: Prof. Dr. Eşref Buharalı, d.1951 Kerkük, Ankara Üniversitesi DTCF Tarih Bölümü emekli öğretim üyesi.

KK2: Prof. Dr. Üçler Bulduk, d.1962 Ankara, Ankara Üniversitesi DTCF Tarih Bölümü ögretim üyesi.

KK3: Prof. Dr. Saadettin Gömeç, d. 1964 Sinop, Ankara Üniversitesi DTCF Tarih Bölümü öğretim üyesi.

KK4: Prof. Dr. Abdullah Gündoğdu, d.1967 Çorum, Ankara Üniversitesi DTCF Tarih Bölümü öğretim üyesi. 
